\title{
Effect of Combined Extrusion and Rolling Parameters on Mechanical and Corrosion Properties of New High Strength Al-Mg Alloy
}

\author{
Kweon-Hoon Choi ${ }^{1,2}$, Bong-Hwan Kim ${ }^{2, *}$, Da-Bin Lee ${ }^{2}$, Seung-Yoon Yang ${ }^{2}$, Nam-Seok Kim ${ }^{2}$ (D) Seong-Ho Ha ${ }^{2}$, \\ Young-Ok Yoon ${ }^{2}$, Hyun-Kyu Lim ${ }^{2}$ and Shae-Kwang Kim ${ }^{2, *}$ \\ 1 Industrial Technology, Korea University of Science and Technology, Daejeon 34113, Korea; \\ kchoi74@kitech.re.kr \\ 2 Advanced Process and Materials R\&BD Group, Korea Institute of Industrial Technology, \\ Incheon 21999, Korea; dabin25@kitech.re.kr (D.-B.L.); sy8357@kitech.re.kr (S.-Y.Y.); \\ kimns@kitech.re.kr (N.-S.K.); shha@kitech.re.kr (S.-H.H.); veryoon@kitech.re.kr (Y.-O.Y.); \\ hklim@kitech.re.kr (H.-K.L.) \\ * Correspondence: bonghk75@kitech.re.kr (B.-H.K.); shae@kitech.re.kr (S.-K.K.); \\ Tel.: +82-10-5058-5837 (B.-H.K.)
}

\section{check for}

updates

Citation: Choi, K.-H.; Kim, B.-H.; Lee, D.-B.; Yang, S.-Y.; Kim, N.-S.; Ha, S.-H.; Yoon, Y.-O.; Lim, H.-K.; Kim, S.-K. Effect of Combined Extrusion and Rolling Parameters on

Mechanical and Corrosion Properties of New High Strength Al-Mg Alloy. Metals 2021, 11, 445. https:// doi.org/10.3390/met11030445

Academic Editors: Andrew Kennedy and Beatriz López Soria

Received: 18 January 2021

Accepted: 1 March 2021

Published: 8 March 2021

Publisher's Note: MDPI stays neutral with regard to jurisdictional claims in published maps and institutional affiliations.

Copyright: (c) 2021 by the authors. Licensee MDPI, Basel, Switzerland. This article is an open access article distributed under the terms and conditions of the Creative Commons Attribution (CC BY) license (https:// creativecommons.org/licenses/by/ $4.0 /)$.
Abstract: High strength Al-Mg alloy is an attractive material that has the characteristic of increasing both strength and elongation by adding more solute $\mathrm{Mg}$. However, there is a limitation in the oxidation issue during the casting process when it contains high amounts of solute $\mathrm{Mg}$. $\mathrm{New} \mathrm{Al}-\mathrm{Mg}$ alloy was developed using $\mathrm{Mg}+\mathrm{Al}_{2} \mathrm{Ca}$ master alloy by making a stable $\mathrm{CaO} / \mathrm{MgO}$ mixed layer that no significant oxidation occurred. Here, the intergranular corrosion (IGC), electrochemical, and mechanical properties of new Al-Mg alloys fabricated through a combined process of extrusion and cold rolling were studied after the specimens went through artificial aging heat treatment at $200{ }^{\circ} \mathrm{C}$. The results show that the grain size and the volume fraction of anodic $\beta$-precipitation $\left(\mathrm{Mg}_{2} \mathrm{Al}_{3}\right)$ forming on the grain boundary influence the intergranular corrosion results. Corrosion potential and current density were achieved by potentiodynamic polarization electrochemical test. The results show that corrosion potential remains irrespective of the manufacturing process, while current density increases with artificial aging treatment. Both hardness and tensile mechanical properties decrease on cold rolled specimens after the heat treatment, while increase in extrusion and annealed specimens.

Keywords: Al-Mg alloy; high-strength; lightweight; mechanical properties; electrochemical properties; intergranular corrosion

\section{Introduction}

Al-Mg alloys have many outstanding characteristics, such as decent mechanical properties, formability, low cost, corrosion resistance, and electrical conductivity, which leads to a wide range of applications [1-3]. Al-Mg alloys are the most widely used solid solution hardening alloys. It is a remarkably intriguing alloy because both strength and ductility increased simultaneously by adding solute $\mathrm{Mg}$ atoms. Al-Mg alloys with a high amount of solute $\mathrm{Mg}$ cast to reach better mechanical properties [4]. $\mathrm{Mg}$ atoms can be added up to $4.5 \mathrm{wt} \%$ in Al-Mg alloy because there is an oxidation problem in the casting process owing to the high affinity to oxygen with $\mathrm{Mg}$. To solve the oxidation problem, $\mathrm{Mg}+\mathrm{Al}_{2} \mathrm{Ca}$ master alloy was used instead of using pure $\mathrm{Mg}$ master alloy to make the stable $\mathrm{CaO} / \mathrm{MgO}$ mixed layer $[5,6]$.

Several technologies, such as hot extrusion, cold rolling, and annealing have been studied so far to achieve the high performance of wrought Al-Mg alloys. Hot extrusion is a widely used forming method on aluminum alloy [1]. The thermomechanical process of the new Al-Mg alloy needs to be studied more because many extrusion parameters, such as extrusion speed, ration, and billet temperature affect the properties. Cold rolling 
is the crucial process in wrought Al-Mg alloys to increase the mechanical properties. In this study, the new process of Al-Mg alloy, which is the combined process of hot extrusion and cold rolling, was developed due to the several benefits at the industrial level. This process needs to be understood well in mass production of wrought high $\mathrm{Mg}$ contained Al-Mg alloys because it does not need a huge installment, such as a hot rolling machine at the mass production level. So, the new process of high $\mathrm{Mg}$ contained $\mathrm{Al}-\mathrm{Mg}$ alloy was investigated in this research.

Still, some problems of high Mg contained Al-Mg alloy need to be solved for the application as structural materials, such as intergranular corrosion. Al-Mg alloys are susceptible to intergranular corrosion (IGC) and stress corrosion cracking (SCC) in a harsh environment exposed to $50 \sim 200{ }^{\circ} \mathrm{C}$ for a long time due to the formation of anodic $\beta$ $\mathrm{Mg}_{2} \mathrm{Al}_{3}$ precipitation at grain boundaries. This phenomenon caused the electrochemical heterogeneity of the aluminum matrix and grain boundary. IGC causes some grains to detach from the matrix, which leads to sudden destruction $[7,8]$. Current research generally discussed the relationship between intergranular corrosion susceptibility and a factor of microstructure. This factor can be grain size, grain boundary type, dislocation density, and texture, etc. However, this needs to be understood at once depending on the manufacturing process of Al-Mg alloy [9-14].

In this research, wrought Al-Mg alloys fabricated through a combined process of hot extrusion, cold rolling, and annealing have been investigated so far. The specimen with each manufacturing process was sensitized at $200{ }^{\circ} \mathrm{C}$ for $45 \mathrm{~min}$. Intergranular corrosion, polarization curve test, and tensile test were conducted to evaluate each manufacturing process. Those properties were investigated by studying the correlation between the experimental results and microstructure. This research can help to develop the novel high strength aluminum plates as light-weight structural materials.

\section{Materials and Methods}

The billets size with $178 \mathrm{~mm}$ diameter and $400 \mathrm{~mm}$ length were prepared by continuous casting. The chemical composition of new AlMg6 billet is $\mathrm{Mg} 6.04 \mathrm{wt} \%$, Ti $0.0614 \mathrm{wt} \%$, Si $0.049 w \mathrm{t} \%$, Fe $0.075 \mathrm{wt} \%$, Ca $0.0186 \mathrm{wt} \%$. The billets were homogenized at $420{ }^{\circ} \mathrm{C}$ for $8 \mathrm{~h}$, then hot extruded to a thickness of $12 \mathrm{~mm}$. The extrusion experiment was conducted using a plate extruder with a billet temperature of $420^{\circ} \mathrm{C}$ and a die temperature of $420^{\circ} \mathrm{C}$. The extrusion ratio was 21.7. The ram speed kept maintaining $1.0 \mathrm{~mm} / \mathrm{s}$ during the entire extrusion process. Table 1 . shows that the detailed manufacturing process of new Al-6Mg alloy.

Table 1. Detailed manufacturing process of new Al-6Mg alloy.

\begin{tabular}{|c|c|c|}
\hline Specimen & Detailed Manufacturing Process & Sensitization \\
\hline${ }^{*} \mathrm{E}$ & Extrusion $(12 \mathrm{~mm})$ & - \\
\hline${ }^{*} \mathrm{ES}$ & Extrusion $(12 \mathrm{~mm})$ & $200^{\circ} \mathrm{C}$ for $45 \mathrm{~min}$ \\
\hline$* \mathrm{CR}$ & $\begin{array}{l}\text { Extrusion }(12 \mathrm{~mm}) \rightarrow \text { Cold Rolling }(6 \mathrm{~mm}) \rightarrow \text { Annealing }\left(350^{\circ} \mathrm{C} \text { for } 3 \mathrm{~h}\right) \\
\rightarrow \text { Cold Rolling }(1 \mathrm{~mm})\end{array}$ & 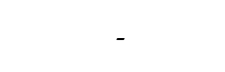 \\
\hline * CRS & $\begin{array}{l}\text { Extrusion }(12 \mathrm{~mm}) \rightarrow \text { Cold Rolling }(6 \mathrm{~mm}) \rightarrow \text { Annealing }\left(350^{\circ} \mathrm{C} \text { for } 3 \mathrm{~h}\right) \\
\rightarrow \text { Cold Rolling }(1 \mathrm{~mm})\end{array}$ & $200^{\circ} \mathrm{C}$ for $45 \mathrm{~min}$ \\
\hline${ }^{*} \mathrm{~A}$ & $\begin{array}{l}\text { Extrusion }(12 \mathrm{~mm}) \rightarrow \text { Cold Rolling }(6 \mathrm{~mm}) \rightarrow \text { Annealing }\left(350^{\circ} \mathrm{C} \text { for } 3 \mathrm{~h}\right) \\
\rightarrow \text { Cold Rolling }(1 \mathrm{~mm}) \rightarrow \text { Annealing }\left(350^{\circ} \mathrm{C} \text { for } 3 \mathrm{~h}\right)\end{array}$ & - \\
\hline${ }^{*}$ AS & $\begin{array}{l}\text { Extrusion }(12 \mathrm{~mm}) \rightarrow \text { Cold Rolling }(6 \mathrm{~mm}) \rightarrow \text { Annealing }\left(350^{\circ} \mathrm{C} \text { for } 3 \mathrm{~h}\right) \\
\rightarrow \text { Cold Rolling }(1 \mathrm{~mm}) \rightarrow \text { Annealing }\left(350^{\circ} \mathrm{C} \text { for } 3 \mathrm{~h}\right)\end{array}$ & $200^{\circ} \mathrm{C}$ for $45 \mathrm{~min}$ \\
\hline
\end{tabular}

* E: extrusion, CR: cold-rolling, A: annealing, ES: extrusion with sensitization heat treatment, CRS: cold-rolling with sensitization heat treatment, AS: annealing with sensitization heat treatment.

Next, the plates were cold rolled to a thickness of $6 \mathrm{~mm}$ in 6 passes. The cold-rolled sheets annealed at $350{ }^{\circ} \mathrm{C}$ for $3 \mathrm{~h}$, and then another cold rolled to $1 \mathrm{~mm}$ in 4 passes. The final annealing condition was $350{ }^{\circ} \mathrm{C}$ for $3 \mathrm{~h}$. Test specimens were sensitized by aging at $200{ }^{\circ} \mathrm{C}$ for $45 \mathrm{~min}$. The specimens were machined with a dimension of $30 \mathrm{~mm} \times 50 \mathrm{~mm}$ with $1 \mathrm{~mm}$ to evade the thickness effect depending on a different process. The grain size of the alloys with each manufacturing process was determined using optical microscopy 
following polishing to a 1-micron diamond suspension followed by electro-etching in Barker's reagent.

The IGC susceptibility was performed by nitric acid mass loss test (NAMLT, ASTM standard G67-04) [15]. After the test, the specimens were prepared by mechanical polishing, then etched in $10 \%$ phosphoric acid at room temperature for the $30 \mathrm{~s}$. An optical microscope (OM, Nikon MA200, Tokyo, Japan) was used to understand the relationship between microstructure and IGC susceptibility. Electrochemical tests were conducted on at least three times from each process of $\mathrm{Al}-\mathrm{Mg}$ alloy plate by using potentiostat equipment (AMETEK VersaSTAT, Princeton, NJ, USA) in a three-electrode cell filled with $3.5 \mathrm{wt} \%$ of $\mathrm{NaCl}$ solution. The temperature of the corrosion solution was kept at room temperature. The working electrode was the Al-Mg alloy sheet, the counter electrode was a graphite plate, and the reference electrode was silver/silver chloride $(\mathrm{Ag} / \mathrm{AgCl})$. The exposed surface area of the Al-Mg alloy was $1 \mathrm{~cm}^{2}$. All tests were repeated at least five times. Vickers hardness measurements were measured by hardness tester with $2.942 \mathrm{~N}$ for $10 \mathrm{~s}$. Each hardness result is the average of 10 individual measurements except maximum and minimum value. The uniaxial tensile test was conducted by the UTS machine for each manufacturing process at least 3 times, respectively. The specimens of tensile tests were machined followed ASTM E8 standard with a $50 \mathrm{~mm}$ gauge length.

\section{Results}

The phase fractions of AlMg6 alloy were computed using J.Mat.Pro (Sente Software Ltd., UK). Equilibrium phase fractions were calculated as a function of temperature in Figure 1. According to the figure below, the anodic $\beta$-precipitation fraction increased until the temperature below $275{ }^{\circ} \mathrm{C}$. The temperature of $200{ }^{\circ} \mathrm{C}$ for $45 \mathrm{~min}$ was selected as the sensitization heat treatment condition in this study. The anodic $\beta$-precipitation tends to form at grain boundary occurring on the intergranular corrosion in Al-Mg alloy system.

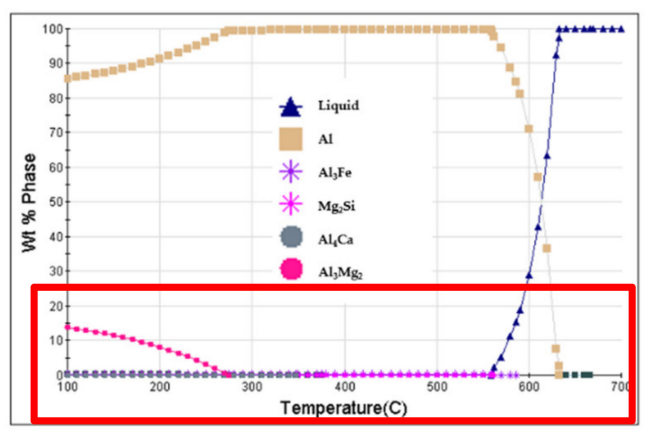

(a)

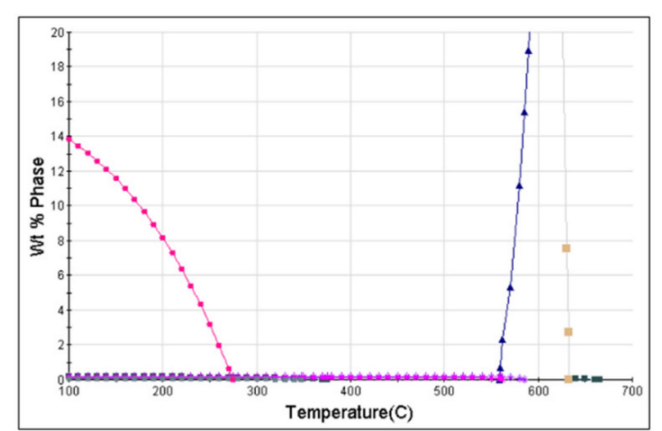

(b)

Figure 1. (a) Calculated equilibrium phase fraction as a function of temperature; (b) close inspection of $y$-axis (weight percent of equilibrium phase fraction as a function of temperature).

Figure 2 represents the microstructure image after the method representing precipitation on grain boundary, which shows no precipitation on grain boundary (a), while precipitation was represented by a black line (b). Phosphoric acid is the general method to selectively etch the $\beta$-precipitation on grain boundary $[3,10]$.

IGC is a type of corrosion where the grain boundaries of crystallites are more susceptible to corrosion than their matrix so that the formation of micro-galvanic cells between grain boundary and matrix occurs [11]. This phenomenon causes grains detached from the samples, which leads to sudden destruction. Figure 1 shows that the mass loss results of the sensitized Al-Mg specimen with each process. The results show that the mass loss results of each process increased dramatically in sensitization treatments. Figure 3 shows the mass loss results of the specimens E, ES, CR, CRS, A, and AS were measured as 2.65, 46.98, 1.47, $21.91,5.14$, and $39.96 \mathrm{mg} / \mathrm{cm}^{2}$. It shows that cold-rolled specimen shows the best IGC resistance for both as-received and sensitized state compared to extruded and annealed 
specimen. Specimen A is more susceptible to IGC than specimen E, while specimen ES shows higher IGC susceptibility than specimen AS.

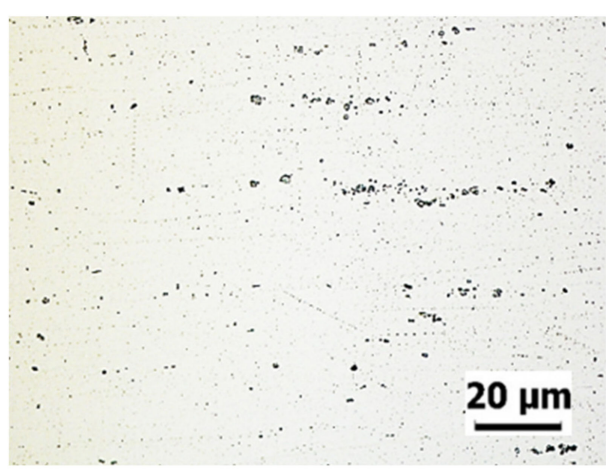

(a)

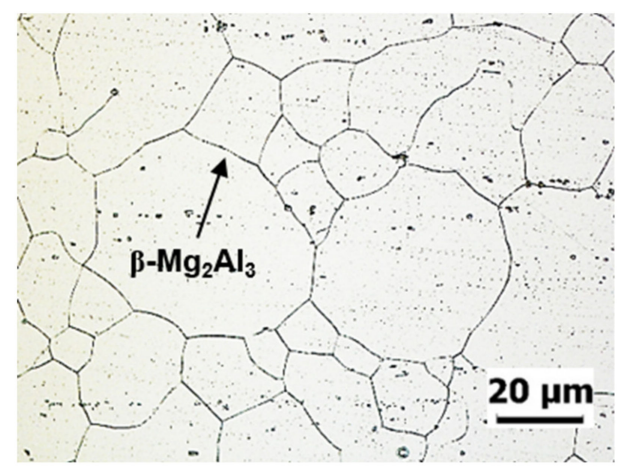

(b)

Figure 2. The microstructure of the extruded AlMg6 alloy with the specimen of (a) E and (b) ES etched by phosphoric acid etchant. The phase with black line in $(\mathbf{b})$ represents the $\beta-\mathrm{Mg}_{2} \mathrm{Al}_{3}$ precipitation.

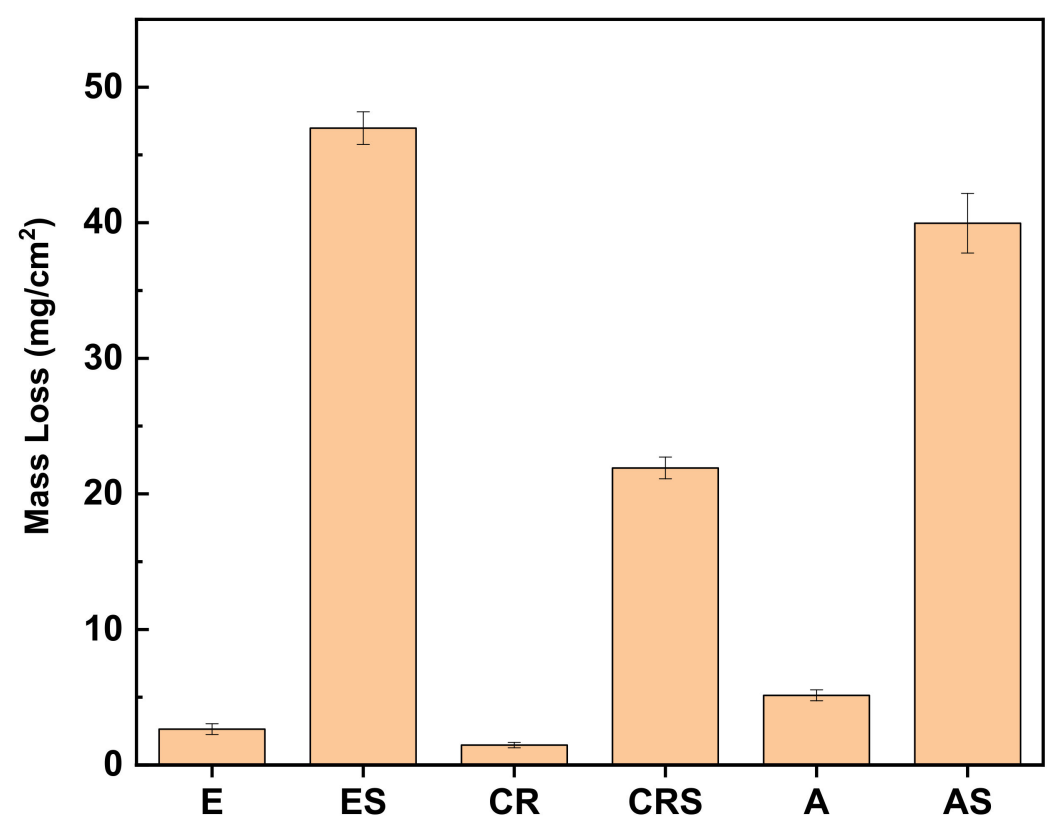

Figure 3. Nitric acid mass loss test (NAMLT) results of E, ES, CR, CRS, A, and AS.

IGC behavior can be explained by several factors, such as the grain size, grain boundary types, and the distribution of anodic precipitation, etc. [10]. How the grain size affects the intergranular corrosion behavior has not been clearly understood yet. Several studies have stated that the microstructure with large grain size has less susceptibility to intergranular corrosion [12,13].

Polarization photomicrographs for each manufacturing process of new $\mathrm{Al}-6 \mathrm{Mg}$ alloy in Figure 4. The grain size of specimen E, ES, CR, CRS, A, and AS was measured as $41.81,40.31,19.09,19.81,22.03$, and $21.81 \mathrm{um}$, respectively. There is no such difference in grain size as the sensitization heat treatment has been done. In the current research, the susceptibility of IGC in as-received condition shows as follows: specimen $\mathrm{CR} \leq \mathrm{E}<\mathrm{A}$. This can be explained because precipitation does not form on the grain boundary much so that the susceptibility of IGC in the as-received condition is low in all cases. On the other hand, the results of IGC susceptibility in sensitized heat treatment follows the order of CRS < AS < ES. By comparing the IGC results of ES and AS, the susceptibility to IGC increases as the grain size increases. 


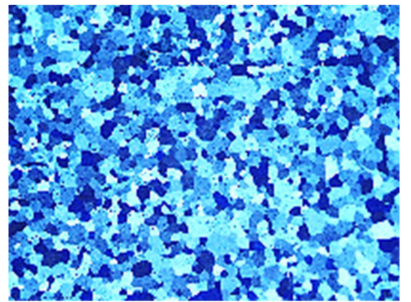

(a)

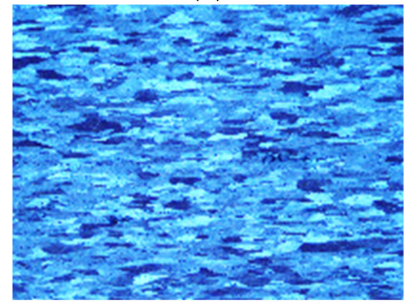

(d)

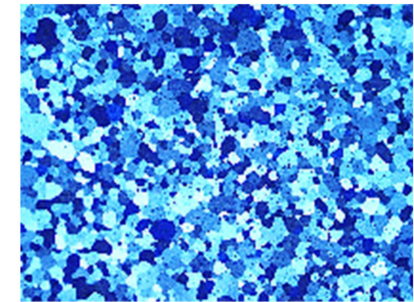

(b)

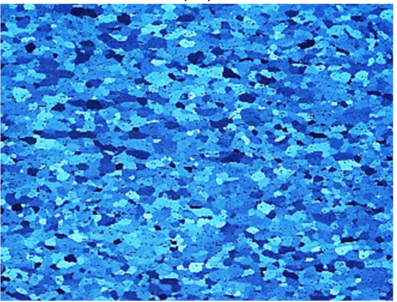

(e)

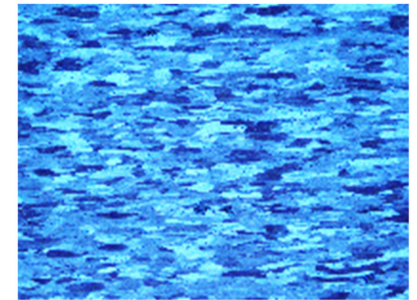

(c)

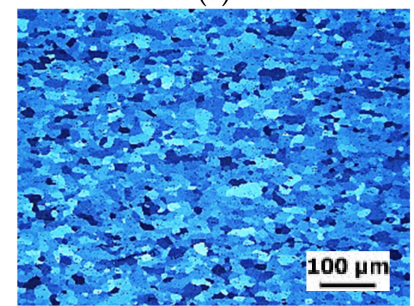

(f)

Figure 4. Optical micrographs of (a) E, (b) ES, (c) CR, (d) CRS, (e) A, and (f) AS (electro etching).

In conclusion, an Al-Mg alloy sheet with large grain size is more susceptible to intergranular corrosion as the sensitization heat treatment is long enough to cover the grain boundary by anodic $\beta$-precipitation.

Although the grain size is an important factor for IGC susceptibility, grain boundary type is noteworthy to evaluate the IGC susceptibility. High angle grain boundaries (HAGBs) tend to be more susceptible to IGC than low angle grain boundaries (LAGBs) due to the grain boundary precipitation [14]. As the degree of cold working increases, the fraction of LAGB also increases [15]. Figure 5 represents the attacked microstructure with $10 \% \mathrm{H}_{3} \mathrm{PO}_{4}$ for $25 \mathrm{~min}$, which is the method for specifically attacked anodic $\beta$-precipitation in $\mathrm{Al}-\mathrm{Mg}$ alloys. This shows that the grain size of ES is bigger than AS so that the susceptibility of IGC follows the same trend. However, it does not follow in the as-received condition. Even the grain size is bigger in E, and the IGC resistance of $\mathrm{E}$ shows better in $\mathrm{A}$. It can be concluded that the grain size is the main factor for the IGC rates when the specimen is sensitized, while the grain boundary type tends to be more important for the as-received samples and sensitized cold-rolled samples. The microstructure of the attacked surface for CR and CRS is shown in Figure 5c,d.

Previous studies show that the susceptibility of IGC decreases as the degree of cold rolling reduction ratio increases due to the high-volume fraction of LAGB, which is known as having benefits on IGC susceptibility [15-17]. Other researches show that the low coincident site lattice (CSL), which is known as a special grain boundary in previous research, can improve the physical properties of the alloy $[10,11,15]$. Coincident site lattice describes the degree of coincidence of lattice sites on grain boundaries [18]. Further analysis needs to be discussed later how the special grain boundaries affect intergranular corrosion of Al-Mg alloy by adjusting the volume fraction of the grain boundary in the microstructure. The susceptibility of IGC can be controlled by microstructure evolution depending on the manufacturing process.

To understand the corrosion susceptibility of a new Al-Mg sheets with each process, polarization curve tests were conducted on the specimen in $3.5 \mathrm{wt} . \%$ of $\mathrm{NaCl}$ solutions [11]. Figure 6a represents potentio-dynamic curves for each process, and the summary of (b) corrosion potential $\left(\mathrm{E}_{\mathrm{corr}}\right)$ and $(\mathrm{c})$ current density $\left(\mathrm{i}_{\mathrm{corr}}\right)$ results. Corrosion potential represents how the corrosion initiation is sensitive, and the corrosion density results suggest the corrosion rates. 


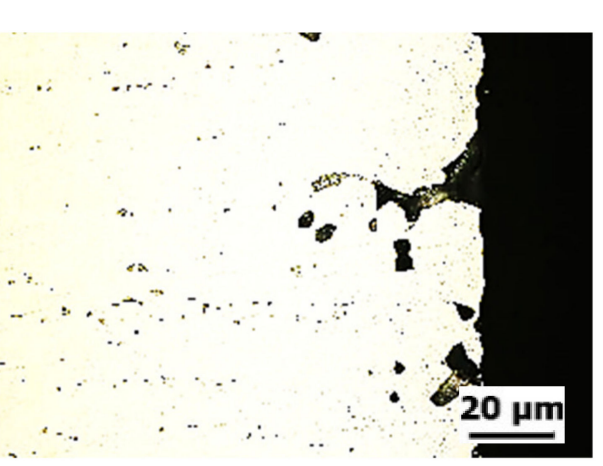

(a)

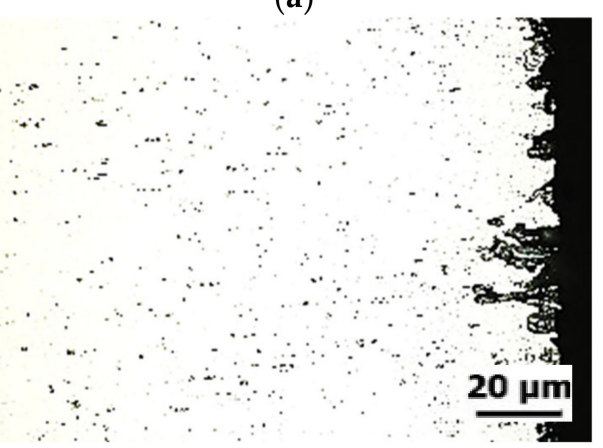

(c)

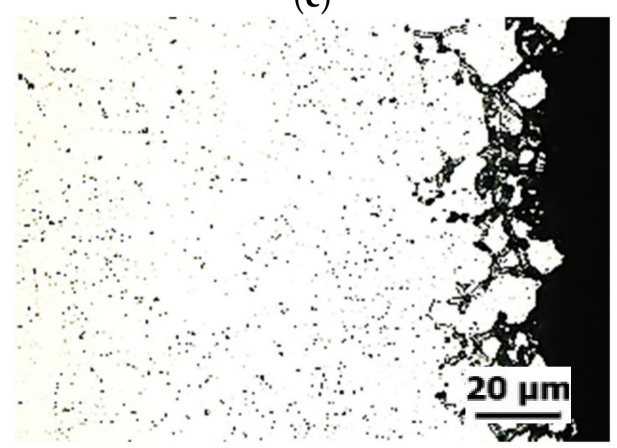

(e)

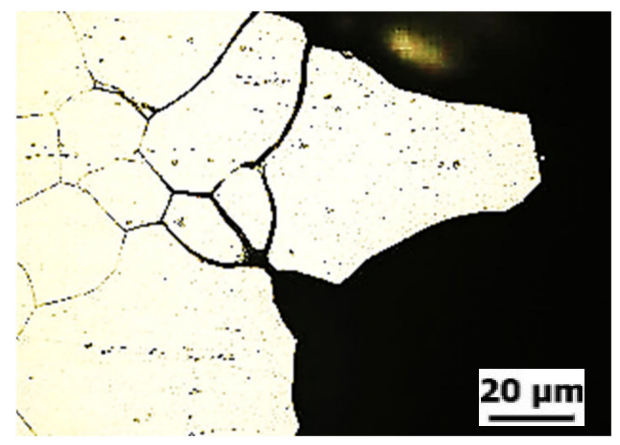

(b)

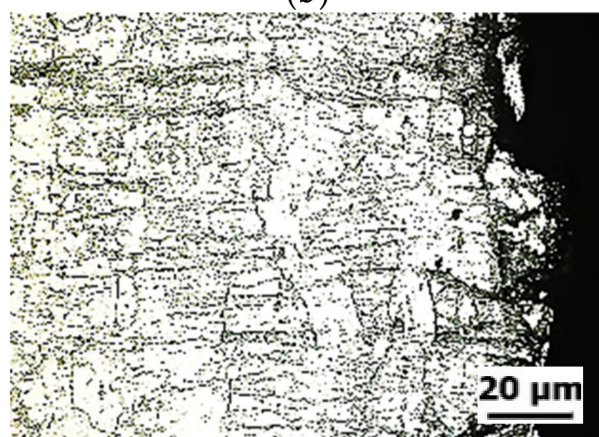

(d)

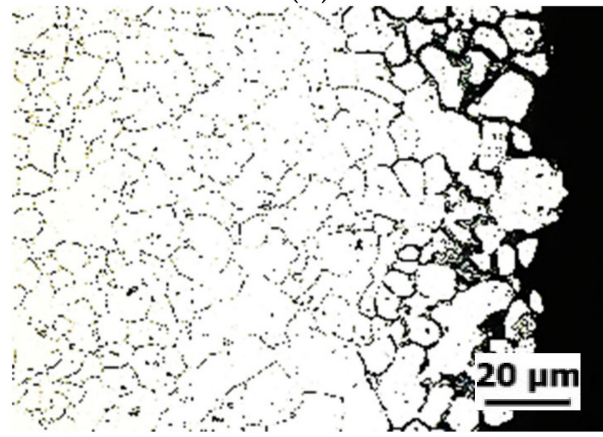

(f)

Figure 5. Microstructure of attacked surface by IGC (a) E, (b) ES, (c) CR, (d) CRS, (e) A, and (f) AS, etched by phosphoric acid for $25 \mathrm{~min}$.

According to the polarization curve in Figure 6, corrosion potential remained irrespective of both the manufacturing process and sensitization heat treatment. Conversely, the current density results are significantly affected by the process. R.K. Gupta et al. states that low-temperature sensitization tends to lead to increasing the volume fraction of anodic $\beta$ precipitation, which results in increased current density value [19]. Compared to the results between specimen $\mathrm{E}$ and $\mathrm{A}$, which shows the grain size differences, the latter represents slightly higher current density results. This trend also follows in sensitized samples, which is the specimen ES and AS. Small grain size means increasing the distribution of anodic precipitation on the grain boundary. In Al-Mg alloys, the anodic $\beta-\mathrm{Mg}_{2} \mathrm{Al}_{3}$ precipitation preferably tends to form on the grain boundary [20]. The specimen CR shows the lowest current density results compared to specimen E and A before sensitization heat treatment, while CRS shows the highest current density result among the other process. This can be said that heterogeneous nucleation spots, which are caused by plastic deformation during the cold rolling process, can be acted as increasing current density results of the sensitized cold-rolled specimen. 


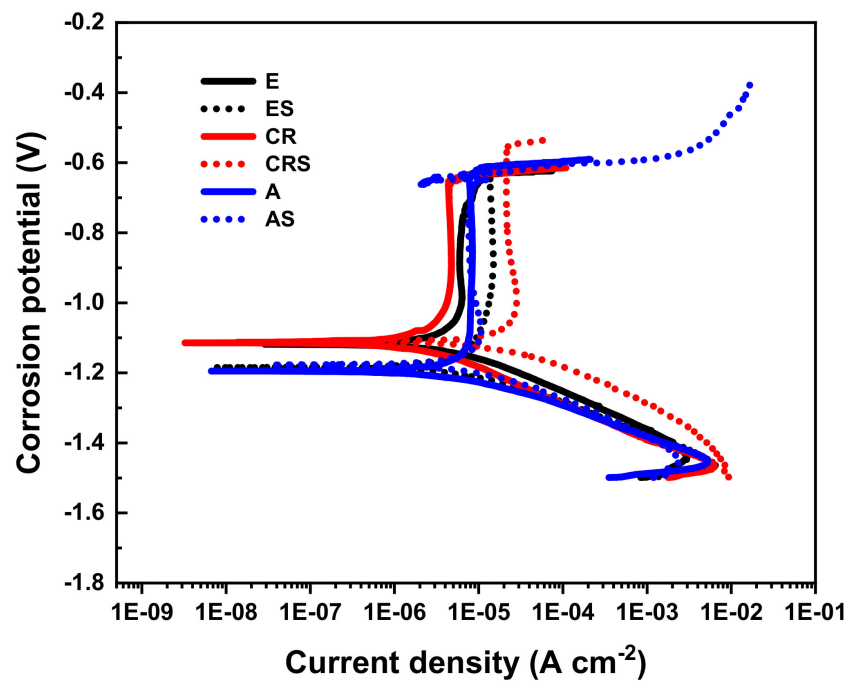

(a)

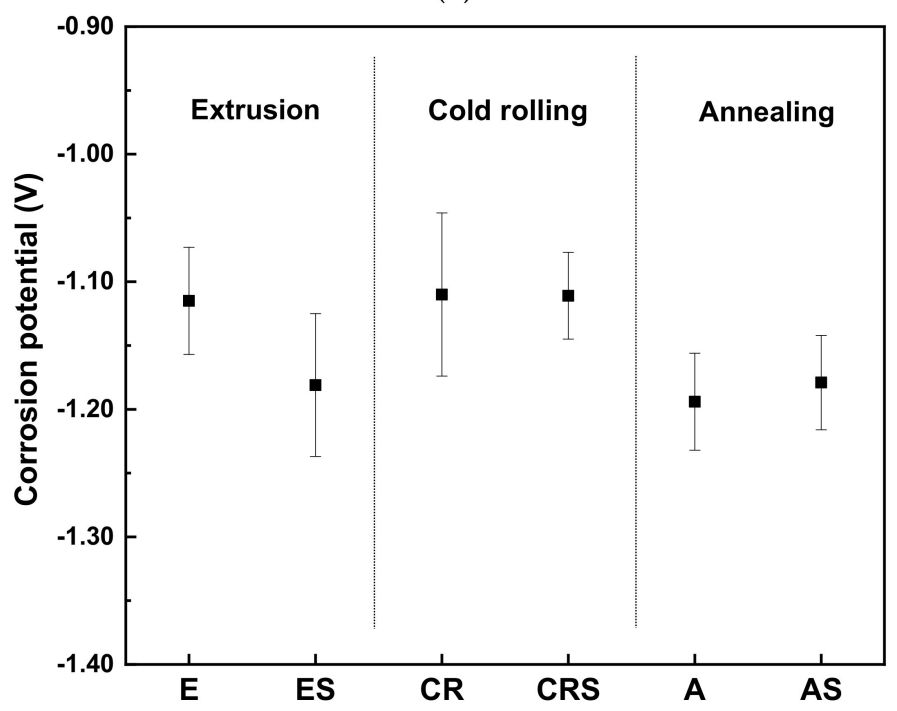

(b)

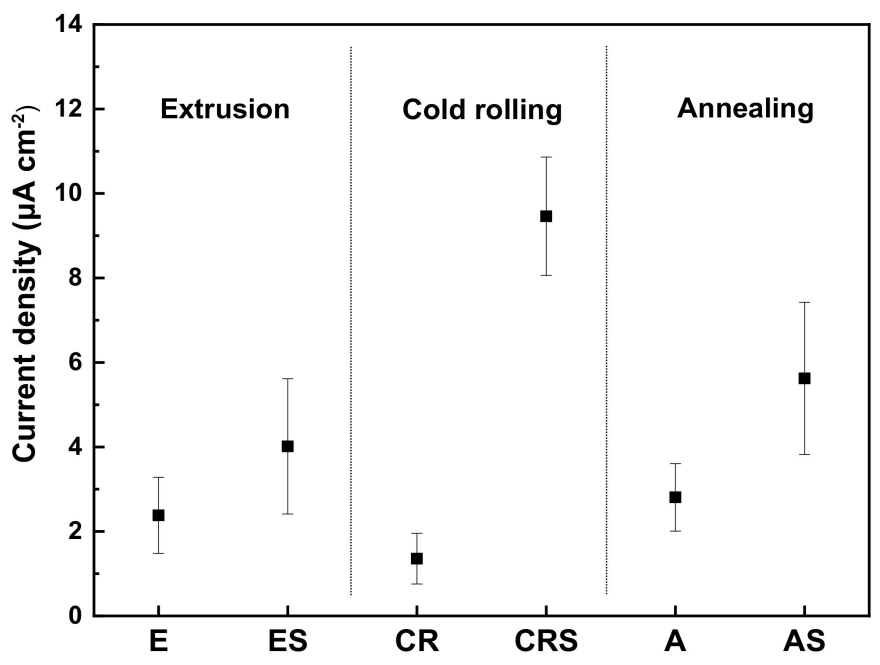

(c)

Figure 6. Electrochemical property test of Al-6Mg alloy for each manufacturing process. (a) Potentiodynamic polarization curve; (b) corrosion potential (c); current density. 
Figure 7 shows that the variation of Vickers hardness with specimen E, ES, CR, CRS, A, and AS. According to the figure below, the hardness results slightly increase in both extruded and annealed specimens during the sensitization heat treatment explained by the precipitation hardening effect. On the contrary, the hardness results of the cold-rolled specimen show different trends because the age softening effect occurs when the specimen is heated in $200{ }^{\circ} \mathrm{C}$ for $45 \mathrm{~min}$. As can be seen in Figure $5 \mathrm{~d}$, anodic precipitations form on the grain boundary indeed during the sensitization heat treatment, but the age softening effect dominates in the specimen $\mathrm{CR}$ so that the hardness results decrease.

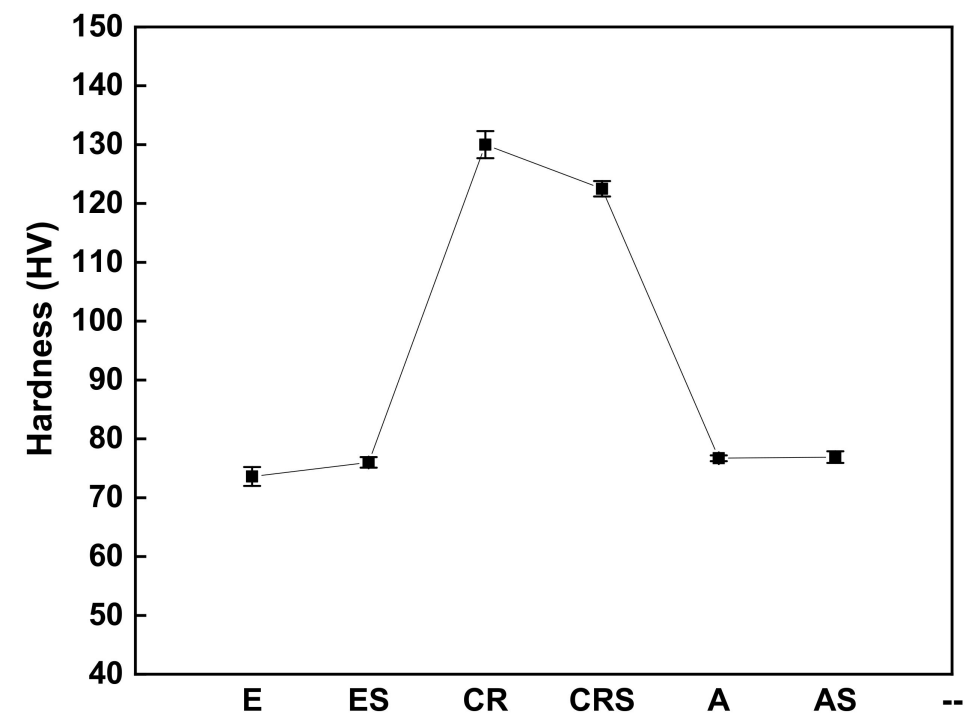

Figure 7. Vickers hardness results of $\mathrm{Al}-6 \mathrm{Mg}$ alloy for each manufacturing process.

Figure 8 shows the mechanical properties of the new Al-Mg6 alloy with each different process. After sensitization heat treatment, mechanical properties between specimen $\mathrm{E}$ and A shows similar values. But, as can be expected in the trend of hardness results, age softening effect dominates in cold-rolled specimens over the precipitation hardening effect. Moreover, the yield strength of A is higher than the yield strength of $\mathrm{E}$. This can be explained as the grain size effect based on the Hall-Petch equation [21].

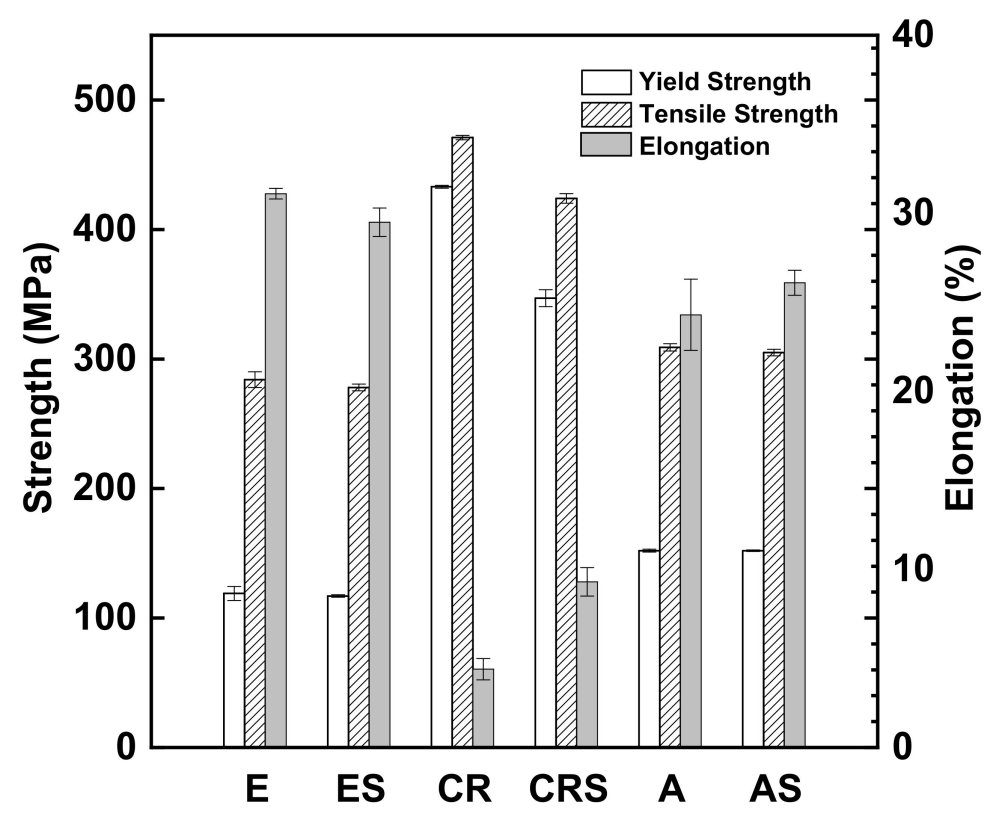

Figure 8. Mechanical properties of Al-6Mg alloy with each manufacturing process. 


\section{Conclusions}

In this work, intergranular corrosion (IGC), electrochemical, and mechanical property tests were conducted for a new Al-6Mg alloy with a newly developed process, which is composed of hot extrusion, cold-rolling, and annealing.

1. IGC resistance increases as the grain size decreases for both specimen $\mathrm{E}$ and $\mathrm{A}$ without sensitization heat treatment. On the other hand, IGC resistance decreases as the grain size increases due to the anodic precipitation formed at the grain boundary continuously during sensitization heat treatment. In cold-rolled states, the mass loss results show the least among the other process in both as-received and sensitization heat treatment.

2. Polarization curve tests were conducted on a sheet made of Al-Mg alloy for each process to evaluate the electrochemical properties in a neutral solution. The corrosion potential results are irrespective of the process, while the corrosion current density, which is closely related to the electrochemical corrosion rates, was increased as the sensitization heat treatment was done. It can be said that the grain size affects the corrosion current density results. Small grain size results in increasing the distribution of anodic precipitation. The sensitized cold-rolled specimen shows the highest results due to the non-homogeneous nucleation spot resulting in increasing the volume fraction of anodic precipitation.

3. Both hardness and tensile results show that the annealed specimen, which has a small grain size, shows higher than extruded samples. There is no such effect on sensitization heat treatment on tensile results between extruded and annealed state, but hardness results show a little bit increased in both conditions. Instead of the precipitate hardening effect, age softening dominates in the sensitized cold-rolled specimen, resulting in decreasing both hardness and tensile results.

Author Contributions: Conceptualization, K.-H.C.; methodology, K.-H.C.; S.-Y.Y.; validation, S.-H.H.; S.-K.K.; formal analysis, K.-H.C.; investigation, K.-H.C.; resources, Y.-O.Y.; data curation, K.-H.C.; D.-B.L.; writing—original draft preparation, K.-H.C.; writing—review and editing, S.-Y.Y.; B.-H.K.; visualization, N.-S.K.; S.-H.H.; supervision, B.-H.K.; project administration, H.-K.L.; S.-K.K.; All authors have read and agreed to the published version of the manuscript.

Funding: This research received no external funding.

Institutional Review Board Statement: Not applicable.

Informed Consent Statement: Not applicable.

Data Availability Statement: Data available in a publicly accessible repository.

Conflicts of Interest: The authors declare no conflict of interest.

\section{References}

1. Sanders, R.E., Jr.; Hollinshhead, P.A.; Simielli, E.A. Industrial Development of Non-Heat Treatable Aluminum Alloys. Mater. Forum 2004, 28, 12.

2. Jin, S.; Tao, N.; Marthinsen, K.; Li, Y. Deformation of an Al-7Mg alloy with extensive structural micro-segregations during dynamic plastic deformation. Mater. Sci. Eng. A 2015, 628, 160-167. [CrossRef]

3. Jain, S.; Lim, M.; Hudson, J.L.; Scully, J. Spreading of intergranular corrosion on the surface of sensitized Al-4.4Mg alloys: A general finding. Corros. Sci. 2012, 59, 136-147. [CrossRef]

4. Huskins, E.; Cao, B.; Ramesh, K. Strengthening mechanisms in an Al-Mg alloy. Mater. Sci. Eng. A 2010, 527, 1292-1298. [CrossRef]

5. Kim, B.-H.; Ha, S.-H.; Yoon, Y.-O.; Lim, H.-K.; Kim, S.K.; Kim, D.-H. Effect of Ca addition on selective oxidation of Al3Mg2 phase in Al-5 mass\% Mg alloy. Mater. Lett. 2018, 228, 108-111. [CrossRef]

6. Ha, S.-H.; Yoon, Y.-O.; Kim, B.-H.; Lim, H.-K.; Lee, T.-W.; Lim, S.-H.; Kim, S.K. Pilling-Bedworth Ratio Approach to Surface Oxidation of Al-Mg Alloys Containing Al2Ca and Its Experimental Verification. Sci. Adv. Mater. 2018, 10, 697-700. [CrossRef]

7. Zhang, D.; Zhang, Z.; Pan, Y.; Jiang, Y.; Zhuang, L.; Zhang, J.; Zhang, X. Current-driving intergranular corrosion performance regeneration below the precipitates solvus temperature in Al-Mg alloy. J. Mater. Sci. Technol. 2020, 53, 132-139. [CrossRef]

8. Meng, C.; Zhang, D.; Zhuang, L.; Zhang, J. Correlations between stress corrosion cracking, grain boundary precipitates and Zn content of Al-Mg-Zn alloys. J. Alloys Compd. 2016, 655, 178-187. [CrossRef] 
9. Yan, J.; Heckman, N.M.; Velasco, L.; Hodge, A.M. Improve sensitization and corrosion resistance of an Al-Mg alloy by optimization of grain boundaries. Sci. Rep. 2016, 6, 26870. [CrossRef] [PubMed]

10. Liu, G.X. Effect of Mg Content on Stress Corrosion Cracking of Al-X Mg Alloys. Int. J. Electrochem. Sci. 2019, 2631-2644. [CrossRef]

11. Kaithwas, C.; Bhuyan, P.; Pradhan, S.; Mandal, S. 'Hall-Petch' type of relationship between the extent of intergranular corrosion and grain size in a Ni-based superalloy. Corros. Sci. 2020, 175, 108868. [CrossRef]

12. Li, S.-X.; He, Y.-N.; Yu, S.-R.; Zhang, P.-Y. Evaluation of the effect of grain size on chromium carbide precipitation and intergranular corrosion of 316L stainless steel. Corros. Sci. 2013, 66, 211-216. [CrossRef]

13. Zhang, R.; Qiu, Y.; Qi, Y.; Birbilis, N. A closer inspection of a grain boundary immune to intergranular corrosion in a sensitised Al-Mg alloy. Corros. Sci. 2018, 133, 1-5. [CrossRef]

14. Hou, J.; Peng, Q.; Lu, Z.; Shoji, T.; Wang, J.; Han, E.-H.; Ke, W. Effects of cold working degrees on grain boundary characters and strain concentration at grain boundaries in Alloy 600. Corros. Sci. 2011, 53, 1137-1142. [CrossRef]

15. ASTM Standard G67-04. Intergranular Corrosion of 5XXX to Nitric Acid (NAMLT Test); ASTM International: West Conshohocken, PA, USA, 2018.

16. Gundu, D.T.; Tile, J.M.; Folorunso, D.O. Effect of Cold Rolling and Annealing Treatments on Microstructure, Impact Toughness and Corrosion Resistance of Cu-12Al-2Ni-5Fe NAB Alloy. Am. J. Eng. Res. 2016, 54, 194-196.

17. Kurc, A.; Kciuk, M.; Basiaga, M. Influence of Cold Rolling on the Corrosion Resistance of Austenitic Steel. J. Achiev. Mater. Manuf. Eng. 2010, 38, 154-162.

18. Fujii, T.; Furumoto, T.; Tohgo, K.; Shimamura, Y. Crystallographic Evaluation of Susceptibility to Intergranular Corrosion in Austenitic Stainless Steel with Various Degrees of Sensitization. Materials 2020, 13, 613. [CrossRef] [PubMed]

19. Gupta, R.; Zhang, R.; Davies, C.; Birbilis, N. Influence of Mg Content on the Sensitization and Corrosion of Al-xMg(-Mn) Alloys. Corrosion 2013, 69, 1081-1087. [CrossRef]

20. D'Antuono, D.S.; Gaies, J.; Golumbfskie, W.; Taheri, M. Direct measurement of the effect of cold rolling on $\beta$ phase precipitation kinetics in 5xxx series aluminum alloys. Acta Mater. 2017, 123, 264-271. [CrossRef]

21. Furukawa, M.; Horita, Z.; Nemoto, M.; Valiev, R.; Langdon, T. Microhardness measurements and the Hall-Petch relationship in an Al-Mg alloy with submicrometer grain size. Acta Mater. 1996, 44, 4619-4629. [CrossRef] 